\title{
IAMJ
}

INTERNATIONAL

AYURVEDIC

MEDICAL JOURNAL

ISSN: 2320-5091

Impact Factor: 6.719

\section{AYURVEDIC MANAGEMENT OF WAGNER'S GRADE II DIABETIC ULCER - A CASE STUDY}

\section{$\underline{\text { Sreeja Pillai }}^{1}, \underline{\text { Nitin Kamat }}^{2}, \underline{\text { Hemant Paradkar }}^{3}, \underline{\text { Anaya Pathrikar }}^{4}$}

${ }^{1}$ MD Scholar, Department of Kayachikitsa, APM Ayurveda Mahavidyalaya, Sion, Mumbai, Maharashtra, India ${ }^{2}$ Honorary Professor, Department of Kayachikitsa, APM Ayurveda Mahavidyalaya, Sion, Mumbai, Maharashtra, India

${ }^{3}$ Associate Professor, Department of Kayachikitsa, APM Ayurveda Mahavidyalaya, Sion, Mumbai, Maharashtra, India

${ }^{4}$ Professor \& HOD, Department of Kayachikitsa, APM Ayurveda Mahavidyalaya, Sion, Mumbai, Maharashtra, India

Corresponding Author: drpuchy14@gmail.com

\section{https://doi.org/10.46607/iamj2309032021}

(Published online: March 2021)

Open Access

(C) International Ayurvedic Medical Journal, India 2021

Article Received: 15/02/2021 - Peer Reviewed: 26/02/2021 - Accepted for Publication: 04/03/2021

\section{(D) Check for updates}

\section{ABSTRACT}

Diabetic ulcer has been a challenge to be tackled since there is deficiency of growth factors and impaired immunity, which can lead to amputation if timely intervention is not done. A 59-year-old male patient with a history of uncontrolled diabetes mellitus for 10 years presented with a non-healing foot ulcer since 1year. He was managed with Ayurvedic internal and external medications at OPD level. After 3 months, the outcome was encouraging with complete epithelialization along with improvement in his generalized complaints like lethargy, irregular bowel movements etc.

Keywords: Diabetes, ulcer, Ayurveda, Mahamanjisthadi, Rasa Sindur, Guduchi Satva.

\section{INTRODUCTION}

Diabetes Mellitus is a chronic clinical syndrome characterised by hyperglycemia, due to deficiency or defective response of insulin. ${ }^{1}$ The global diabetes prevalence in 2019 is estimated to be $9.3 \%$ (463 million 
people), rising to $10.2 \%$ (578 million) by 2030 and $10.9 \% \quad(700$ million $)$ by $2045 .^{2}$ The chronic complications of DM (vascular and nonvascular) are responsible for the majority of morbidity and mortality. The aetiology hints to the burden of longstanding hyperglycaemia and glycosylation of proteins that leads to accumulation of sorbitol and free radicals leading to permanent tissue damage. ${ }^{3}$ The most common neurological complication is peripheral neuropathy that predisposes to ulceration by reducing perception of pain and trauma by foreign bodies, walking or ill-fitting shoes. About $15 \%$ of individuals with diabetes develop foot ulcer. ${ }^{4}$ Risk factors for foot ulcer include male sex, diabetes $>10$ years (poor glycemic control), peripheral neuropathy, peripheral vascular disease and, smoking. ${ }^{5}$ Diabetic wounds become 'stuck' in the inflammatory and proliferative stages of healing which delays closure. Debridement is often required more than once as the healing process can stop or slow down allowing further devitalized tissue to develop. The signs of diabetic wound are delayed healing, increased exudates, bright red/pinkish discoloration of granulation tissue, friable and exuberant tissue, new areas of slough, undermining pain, malodour and wound breakdown ${ }^{6}$ Diabetic wound fluid has been found to contain high levels of proteases which have an adverse effect on wound healing by slowing down or blocking cell proliferation in particular keratinocytes, fibroblasts and endothelial cells. ${ }^{7}$ Treatment with recombinant growth factors is expensive with risk of infection transmission with chances of $30 \%$ recurrence. $^{8}$ So there is a need for a comprehensive approach to tackle the stigma of ulcer leading to amputation by cost effective and time bound management with least recurrence rate with an enhanced immune system.

Vrana may be considered as an upadrava of Prameha. Pramehajanya vranas mostly fall into the category of Dushta vrana. ${ }^{9}$ Ayurveda has detailed scientific protocol for ulcer management (Vranopachara) after examination of the patient for routing the pathology. The present case study is of a diabetic ulcer managed through Ayurvedic principles of Vrana Shodhana, Ropana and Vaikritapaha.

\section{Case Report (Patient Information \& Examination)}

A 59-year-old male with uncontrolled diabetes patient came to our OPD, with a non-healing painless ulcer on the big toe (hallux) of his left leg (plantar surface). He had occasional burning sensation on both feet and numbness in his left foot. He also had complaints of drowsiness, lethargy, constipation, body ache and low appetite.

\section{History of Presenting Illness}

The patient had noticed a burning sensation of feet and pain on pressure and a wound on his left big toe about one year ago. Since there was no pain he ignored, the wound gradually developed into an ulcer, which made the patient discomfort able and he went for antibiotics and debridement. The ulcer didn't heal. The patient is a known diabetic for 10 years. $\mathrm{He}$ is on oral hypoglycemic agents regularly (metformin $500 \mathrm{mg}$ bd, gliclazide $60 \mathrm{mg}$ od). no history of amputation.

Family History - No relevant history.

\section{Personal History}

Sleep -disturbed Appetite-reduced, Bowel -irregular, constipated. Habits - no addictions, BP -140/80 mm Hg P-76/mt, Ht: $170 \mathrm{~cm}$ weight:74 kg, Lab reports, hb$13 \mathrm{~g} \%$ cbc-wnl, lipid profile-wnl, bsl-fbs -216 ppbs320 .

\section{Systemic Examination}

CVS: S1 S2 Normal CNS: Normal RS: Normal, Locomotory: knee joint- flexion, extension painful, restricted.

Local Examination: Diabetic foot

Inspection: Lower limbs, No skin colour change / no hair loss/ no erythema / no swelling

Palpation: No temperature difference; dorsalis pedis, posterior tibial pulse-present

\section{Sensation}

Monofilament test- diminished sensation. Vibration (tuning fork)- diminished., Proprioception-impaired ankle jerk reflex- diminished.

\section{Ulcer Examination}

\section{Inspection}

Site - plantar aspect of left big toe, Size \& shape$2.5 \times 1.5 \mathrm{~cm}$, triangular, $3 \mathrm{~mm}$ depth, number -1 Onsetspontaneous, Edge and margin- inflamed, irregular 
border with sloping edge, Floor - pale reddish, granulation tissue Base-exudate, Discharge- purulent

According to wagner's ulcer classification system, grade 2

\section{Palpation}

Skin temperature - cold Capillary filling time $-2 \mathrm{sec}$ Tenderness- nil.

\section{Ashta Sthaana Pariksha}

Nadi - Vatapittaj Drshti - Timira (Dviteeya Patala), Mutra - Bahu, Aavila Sparsha - Haani, Mala - Badham Shabda - Saadharanam, Jihva -Saama Aakrti Madhyama

\section{Samprapti Ghataka}

Hetu - Madhura, Amla, Lavana Atiyoga, Eka Sthaana Aasana, Vidhi Varjitanidra, Ahara; Vishaada

Purva Rupa- Daaha, Trshna, Arati, Gouravam, Klamam

Dosha - Vata (Vyana, Apana, Samana), Pitta (Pachaka), Kapha (Avalambaka)
Dushya - Rasa, Rakta, Mamsa, Meda, Kleda, Pureesha, Mutra

Srotas - Annavaha, Medovaha, Rasavaha, Raktavaha

Roga Marga-Bahya

Rogibala - Avara Hetubala - madhyama

Agni -Vishama

Samprapti Bala - Madhyama

Koshta-Krura Lakshana Bala - Madhyama

Kaala-Purana. Roga Bala-Madhyama

\section{Chikitsa}

The tedious steps of "Vrana Ropana" has been inculcated foreseeing every step back by Ayurvedic standard protocols. Acharya Sushruta has advised to follow Vrana Chikitsa in Madhumeha Janya Vrana. As it was an OPD case, the patient was advised to follow Parisheka and Taila Pichu Dharana at home along with internal medicines.

Table 1:

\begin{tabular}{|c|c|c|c|}
\hline TIME PERIOD & MEDICINE & DOSE \& ANUPANA & OUTCOME \\
\hline $\begin{array}{l}14 \text { days } \\
06.06 .20- \\
20.06 .20\end{array}$ & $\begin{array}{l}\text { Arogyavardhini } \\
\text { Gandhak rasayan } \\
\text { Kaishor guggulu } \\
\text { Triphala guggulu }\end{array}$ & $\begin{array}{l}250 \mathrm{mg} \text { tds(warm water) } \\
250 \mathrm{mg} \text { tds(warm water) } \\
250 \mathrm{mg} \text { bd (warm water) } \\
250 \mathrm{mg} \text { bd (warm water) }\end{array}$ & Not much change \\
\hline $\begin{array}{l}14 \text { days } \\
20.06 .20- \\
04.07 .20\end{array}$ & $\begin{array}{l}\text { 1. Mahamanjishtadi ks } \\
\text { 2.Rasasindur } \\
\text { 3. Guduchi satva } \\
\text { 4.Triphala guggulu } \\
\text { 5.Triphala dhavana }\end{array}$ & $\begin{array}{l}40 \mathrm{ml}(\text { warm water) } \\
125 \mathrm{mg} \text { tds } \\
500 \mathrm{mg} \text { tds } \\
250 \mathrm{mg} \text { tds }\end{array}$ & $\begin{array}{l}\text { No discharge and foul smell from } \\
\text { wound }\end{array}$ \\
\hline $\begin{array}{l}30 \text { days } \\
04.07 .20- \\
04.08 .20\end{array}$ & $\begin{array}{l}1-4 \text { continue } \\
\text { 5.Jatyadi tail }\end{array}$ & Pichu dharan & $\begin{array}{l}\text { No discharge or foul smell, } \\
\text { occasional fresh bleed, wound } \\
\text { margin, floor healthy. }\end{array}$ \\
\hline $\begin{array}{l}30 \text { days } \\
04.08 .20- \\
05.09 .20\end{array}$ & $\begin{array}{l}1-4 \text { continue } \\
\text { Murivenna }\end{array}$ & Pichu & Healthy granulation tissue \\
\hline
\end{tabular}

\section{Follow Up After Treatment}

After treatment, the patient was called for follow-up with continuation of maha manjishtadi kashayam and Guduchi Satva alone as internal medicine. The patient was thoroughly educated for hygiene, to follow Pathya Ahara and Vihara. He turned for follow up in November and January with complete healing without a mark.

\section{DISCUSSION}

Diabetes mellitus is a cause for secondary immunodeficiency disorder. Chronicity of the disease leads to decreased mitogen-induced lymphoproliferation, defective phagocytosis, decreased chemotaxis. ${ }^{10}$ Although neuropathy and vascular factors are associated with the development of Diabetic foot ulcers, the main factors that are associated with failure to heal these ulcers are pre-existing 
increased serum levels of inflammatory cytokines, including tumor necrosis factor $\alpha(\mathrm{TNF} \alpha)$, G-CSF, GRO, MCP-1, leptin, MMP-9, and resistance to growth factors as PDGF, Beta FGF, TGF, GM-CSF etc. along with reduction in interleukin2 receptor levels. ${ }^{11}$ The spreading nature with chronicity if untreated makes amputation inevitable. Treatment with recombinant growth factors being so expensive with recurrence rate, it is necessary for a more comprehensive approach which is cost effective with rejuvenation of the system. Proper nutrition and regular exercise ensure balance formation and transportation of dhatus. Dhatwagni works for formation of Dhatu and for energy utilization during function of Dhatus. When Preenana is more with Madhura, Amla, Lavana Rasa and energy utilization is less with lack of exercise, it results in accumulation of Kleda Vridhi that predisposes to Snigdha Pichila Vridhi and slowing in circulation that leads to Srotorodha which if persistent lead to Dhatu Agnimandya and impairment of excretion of Mala. ie, Samana Apana Vyana axis dysfunction leading to Santarpanotha Vyadhi in the form of Prameha. Prameha causes susceptibility for affliction of Trimarmas that is considered as Upadravas (complications). ${ }^{12}$ The Apathyacharana of Hetu Sevana when continued, along with Abhishyandi and Vidahi Ahara with Aayaasa (mental and physical) leads to Shotha, Pidaka and eventually Vrana. Pramehaja Vrana is Krchrasaadhya due to Brhat Vyaapana Sheelata and Krchra Ropanatva. Ojovaigunya and Kleda Mala Vridhi predispose to Krimi Pradurbhava that makes it a Yaapya condition that can afflict Uttara Dhatus that can turn to Asadhya Avastha.

Reversal of the condition can be done before reaching Asaadhya Avastha by proper intervention through Ahara, Vihara and Oushadha. Since Snigdha, Pichila, Kleda Vridhi is evident, as per Samanya Vishesha Sidhanta and Prameha Pidaka and Vrana Chikitsa, Apatarpana (Hetu Viparita), Anulomana (Samanavyana-apana axis), Srotoshodhana, Dhatu Prasadana and Ojovardhana should be done.

Maha Manjishtadi Kashayam:

Medodosha Hara, Prasuptihara, Kushtahara, Vata Anulomaka, Rakta Prasadaka, Raktamedo Sroto
Shodhaka. Rasa, Rakta, Mamsa, Meda, Asthi, Majja Pachak Dravyas are present in the Kashayam. The ingredients are Tikta (Kleda, Meda, Laseeka, Pooya Upasoshana), Kashaya Rasa (Kleda, Medo Visoshana; Asra Visoshana) Pradhana with Vishada Guna. Vacha, Haridra, Daruharidra, Nagara, Abhaya, Chitraka, Varuna are Ushna Veerya, Laghu, Ruksha Which Act in Medo Kaphavrta Vata in Prasupti. Aragwadha, Triphala, Kutki, Trivrt are Kaphapittashamana with Anulomana and Vrana Shodhaka. Manjistha, Shariba, Haridra, Darvi, Nimba, Khadira are Kashaya, Tikta, Laghu And Rakta Prasadana and Pitta Kapha Hara. ${ }^{13}$ As per pharmacological studies, wound contracting ability, wound closure, decrease in surface area of wound, tissue regeneration at the wound site and histopathological characteristics has been improved by vascularization, ${ }^{14}$ fibrin deposition (HPX, FN, and collagen), and epithelization. ${ }^{15}{ }^{16}{ }^{17}$ Some of the drugs like Haridra has multiple level of action as Inhibiting the activity of NF-( $\kappa) \mathrm{B}$ transcription factor, reducing the production of TNF- $\alpha$ and IL-1 cytokines, and thereby reducing inflammation; antioxidant activity, enhancing fibroblast migration, granulation tissue formation, collagen deposition, and in general reepithelialization ;Being apoptotic in the early phase of wound healing, thereby eliminating unwanted inflammatory cells from the wound site Remodeling; Improving wound contraction by increasing the production of TGF- $\beta$ and therefore increasing fibroblast proliferation etc. ${ }^{18}$

\section{Rasa Sindur \& Guduchi Satva ${ }^{19}{ }^{20}$}

Rasa Sindur is Pramehahara, Vrana Hara, Yogavahi, Srotoshodhaka, Sheeghra Kriyakari and Balya which make it a best choice in Prameha Vrana with Guduchi as Anupana. For better potentiation, Guduchi Satva was used. Guduchi is Pachana, Deepana, Tridoshahara, Pramehahara, Kushtahara, Krimihara, Dahahara. ${ }^{21}$ As per pharmacological studies, Tinospora facilitate growth factor activation, angiogenesis and granulation tissue formation. ${ }^{22}$

Triphala Guggulu ${ }^{23}$ Triphala Guggulu is Vrana Ropana and Medodoshahara. Triphala is Anulomana, Vrana Shodhana, Ropana, Rasayana. As per pharmacological studies, Triphala significantly 
prevents elevation of IL-4 levels as well as corrects decreased IL-2 and IFN- $\gamma$ levels. ${ }^{24}$

\section{Bahya Upachara}

1. Parisheka With Triphala Parisheka helps in removal of debris from the wound. Triphala Kwath was used for removal of discharge, cleansing of wounds, removing the slough and assisting in wound cleaning.

\section{Pichu Dharana}

a. Jatyadi Tailam -for 30 days

b. Murivenna -for next 30 days

This helped in Shodhana and Ropana Of Vrana.

\section{Pathya \& Apathya:}

Ahara - Anabhishyandi, Laghu, Avidahi Ahara which included Mudga Yusha, Rakta Shali And Shaaka. Ushna Jala Pana. Vihara - Laghu Chankramana, No Divaswapna, No Ratrijagrana.

\section{CONCLUSION}

Ayurveda has scientific protocols for the qualitative reversal of pathological conditions, which if employed in a systematic manner will help in assuring the intended results.
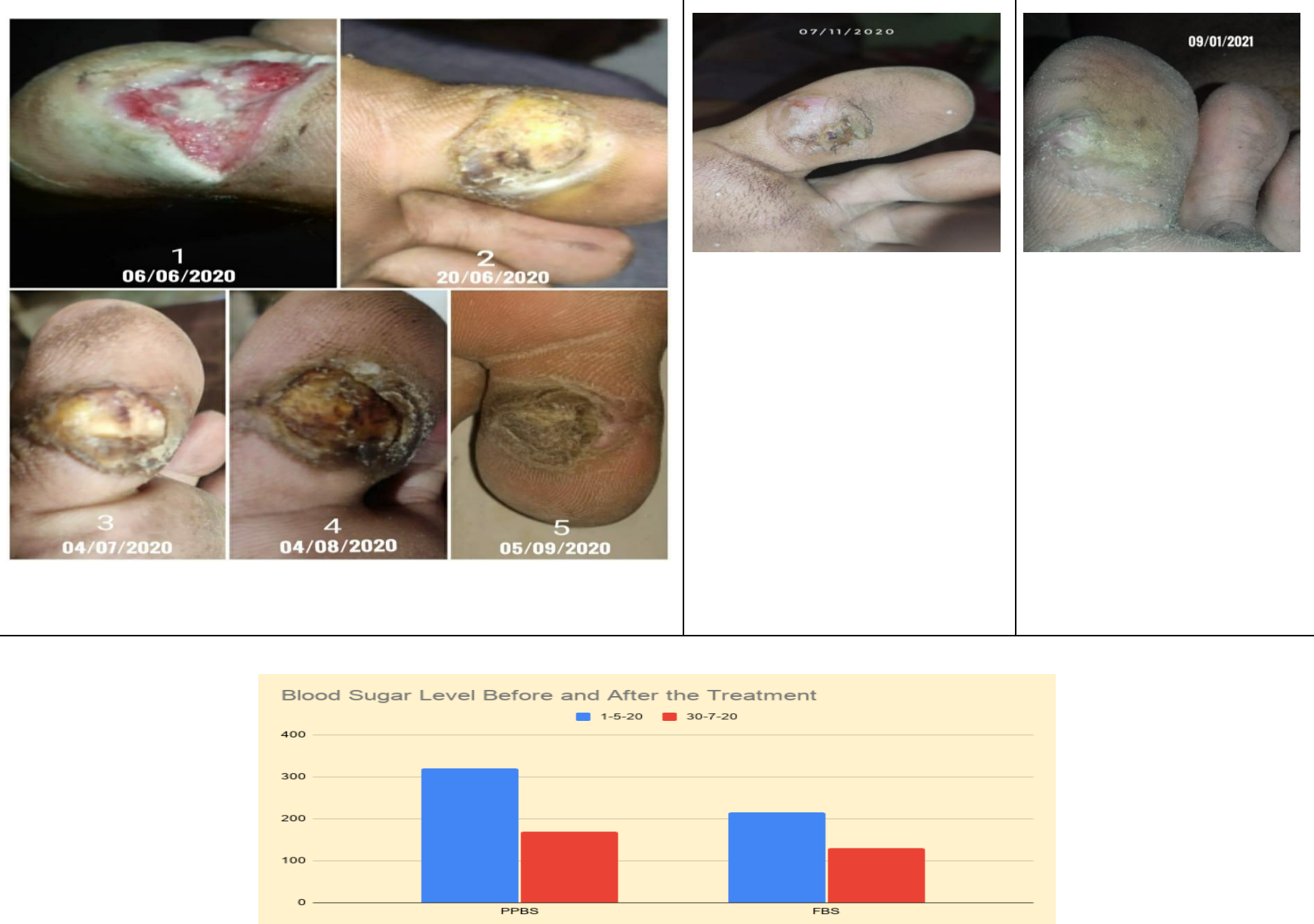

\section{REFERENCES}

1. Diabetes - World Health Organization." https://www.who.int/health-topics/diabetes. "

2. "Global and regional diabetes prevalence estimates forNCBI."

https://www.ncbi.nlm.nih.gov/pubmed/31518657.
3. Giacco F, Brownlee M. Oxidative stress and diabetic complications. Circ Res. 2010;107(9):1058-1070. doi:10.1161/CIRCRESAHA.110.223545.

4. Pendsey SP. Understanding diabetic foot. Int J Diabetes Dev Ctries. 2010 Apr;30(2):75-9. doi: 10.4103/09733930.62596. PMID: 20535310; PMCID: PMC2878694. 
5. Alex R, Ratnaraj B, Winston B, Samson Devakiruba DN, Samuel C, John J, Mohan VR, Prasad JH, Jacob K. Risk factors for foot ulcers in patients with diabetes mellitus - a short report from vellore, South India. Indian J Community Med. 2010 Jan;35(1):183-5. doi: 10.4103/0970-0218.62582. PMID: 20606950; PMCID: PMC2888355.

6. Grey JE, Enoch S, Harding KG. Wound assessment. BMJ. 2006 Feb 4;332(7536):285-8. doi: 10.1136/bmj.332.7536.285. PMID: 16455730; PMCID: PMC1360405.

7. Schultz GS, Chin GA, Moldawer L, et al. Principles of Wound Healing. In: Fitridge R, Thompson M, editors. Mechanisms of Vascular Disease: A Reference Book for Vascular Specialists [Internet]. Adelaide (AU): University of Adelaide Press; 2011.

8. Elahe Mahdipour, Amirhossein Sahebkar, "The Role of Recombinant Proteins and Growth Factors in the Management of Diabetic Foot Ulcers: A Systematic Review of Randomized Controlled Trials", Journal of Diabetes Research, vol. 2020, Article ID 6320514.

9. P.V Sarma Susruta samhita Sutrasthana 22/7 (vol.1) chaukhambha Viswabharati haridas ayurveda series,9.

10. Chinen J, Shearer WT. Secondary immunodeficiencies, including HIV infection. J Allergy Clin Immunol. 2010 Feb;125(2 Suppl 2):S195-203. doi: 10.1016/j.jaci.2009.08.040. Epub 2009 Dec 29. PMID: 20042227; PMCID: PMC6151868.

11. Dinh T, Tecilazich F, Kafanas A, Doupis J, Gnardellis C, Leal E, Tellechea A, Pradhan L, Lyons TE, Giurini JM, Veves A. Mechanisms involved in the development and healing of diabetic foot ulceration. Diabetes. 2012 Nov;61(11):2937-47. doi: 10.2337/db12-0227. Epub 2012 Jun 11. PMID: 22688339.

12. Rajkumar. K. C, Unveiling the truths in Ayurveda, First edition,2017, Page No.229.

13. Acharya Sharangdhara, Sharngadhara Samhita, Madhyam Khanda 2, Jivan Prada Hindi Commentary Editing by Shailaja Srivastava, Chaukhambha orientalia, Varanasi, 2011.p.137/42.

14. Jain N, Jain R, Jain A, Jain DK, Chandel HS. Evaluation of wound-healing activity of Acorus calamus Linn. Nat Prod Res. 2010 Apr; 24(6):534-41. doi: 10.1080/14786410802531782. PMID: 20182947.

15. Budovsky A, Yarmolinsky L, Ben-Shabat S. Effect of medicinal plants on wound healing. Wound Repair Regen. 2015 Mar-Apr;23(2):171-83. doi: 10.1111/wrr.12274. PMID: 25703533.
16. Ghosh PK, Gaba A. Phyto-extracts in wound healing. J Pharm Pharm Sci. 2013;16(5):760-820. doi: 10.18433/j3831v. PMID: 24393557.

17. Maan P, Yadav KS, Yadav NP. Wound Healing Activity of Azadirachta indica A. Juss Stem Bark in Mice. Pharmacogn Mag. 2017 Jul;13(Suppl 2):S316-S320. doi: 10.4103/0973-1296.210163. Epub 2017 Jul 11. PMID: 28808399; PMCID: PMC5538173.

18. Karri VVSR, Gowthama Rajan K, Satish Kumar MN, Rajkumar M (2015) Multiple Biological Actions of Curcumin in the Management of Diabetic Foot Ulcer Complications: A Systematic Review. Trop Med Surg 3: 179. doi:10.4172/2329-9088.1000179.

19. Sadananda SS, Kashinath S, editors. Rasa Tarangini. $11^{\text {th }}$ ed., Ch. 6, Ver. 162-167. New Delhi: Motilal Banarsidass; 2004. p. 135

20. Yadav Ji Trikam Ji Aacharya.Siddha YogaSamgraha, Shree Baidyanath Ayurveda Bhavan Ltd, 8th edition, July 1984.Jwararogadhikara page-4.

21. Sharma R, Kumar V, Ashok BK, Galib R, Prajapati PK, Ravishankar B. Hypoglycemic and anti-hyperglycemic activity of Guduchi Satva in experimental animals. Ayu. 2013 Oct;34(4):417-20. doi: 10.4103/09748520.127726. PMID: 24695802; PMCID: PMC3968707.

22. Hashilkar, Nayana \& Patil, Paragouda \& Bagi, Jayasheela \& Patil, Sunita \& Angadi, Netravathi. (2016). Influence of Tinospora cordifolia on wound healing in wistar rats. International Journal of Basic and Clinical Pharmacology. 923-928. 10.18203/2319. 2003.ijbcp20161546.

23. Sharangdharacharya . Shloka 7/82. 7th ed. Varanasi: Choukhmba Umarbharati Prakashan; 1988. Sharangdhar Samhita Madhyama khand.

24. Belapurkar, Pranoti \& Goyal, Pragya \& Barua, Preeti Tiwari. (2014). Immunomodulatory Effects of Triphala and its Individual Constituents: A Review. Indian journal of pharmaceutical sciences. 76. 467-75.

\section{Source of Support: Nil Conflict of Interest: None Declared}

How to cite this URL: Sreeja Pillai et al:Ayurvedic Management Of Wagner's Grade Ii Diabetic Ulcer - A Case Study. International Ayurvedic Medical Journal \{online\} 2021 \{cited March, 2021\} Available from: http://www.iamj.in/posts/images/upload/657_662.pdf 